\title{
Implementing a Double Dividend: Recycling Ecotaxes Towards Lower Labour Taxes
}

\author{
Antonio Manresa \\ (manresa@pcb.ub.es) \\ Departament de Teoria Econòmica and CREB \\ Universitat de Barcelona \\ 08034-Barcelona, Spain
}

Ferran Sancho

(ferran.sancho@uab.es)

Departament d'Economia

Universitat Autònoma de Barcelona

08193-Bellaterra, Spain

History:

Fist draft April 2002

Revised draft August 2002

This work has been possible thanks to the financial support of the Regidoria de Medi Ambient de l'Ajuntament de Barcelona. Institutional support from research grants SEC2000-0796 and SGR2001-0029 (first author) and SEC2000-0390 and SGR2001-0164 (second author) are also gratefully acknowledged. Stated opinions are those of the authors and therefore do not reflect the viewpoint of the supporting institutions. 


\begin{abstract}
$\underline{\text { Abstract }}$
In this paper we follow the tradition of applied general equilibrium modelling of the Walrasian static variety to study the empirical viability of a double dividend (green, welfare, and employment) in the Spanish economy. We consider a counterfactual scenario in which an ecotax is levied on the intermediate and final use of energy goods. Under a revenue neutral assumption, we evaluate the real income and employment impact of lowering payroll taxes. To appraise to what extent the model structure and behavioural assumptions may influence the results, we perform simulations under a range of alternative model and policy scenarios. We conclude that a double dividend -better environmental quality, as measured by reduced $\mathrm{CO}_{2}$ emissions, and improved levels of employment- may be an achievable goal of economic policy.
\end{abstract}

Keywords: double dividend, tax recycling, ecotaxes.

JEL code: H21, H22, C68 


\section{Introduction}

One of the hottest topics in environmental public economics is the viability of a double dividend ensuing a fiscal reform. This is so both from an empirical and from a theoretical perspective. In the first place, most empirical evidence seems to give support to the assumption that carbon dioxide emissions are the main culprit in the spreading of the so-called greenhouse effect. Therefore tax policies specifically targeted on polluting goods could in principle be used to control $\mathrm{CO}_{2}$ emissions. In the second place, any fiscal reform is bound to have an additional effect on the inefficiency of a given tax system. Whether a new tax (ecotax) or an increase in existing taxes can be adequately designed to reduce emissions (a desirable environmental objective) and at the same time enhance efficiency through tax recycling (a desirable policy goal) is a question that we feel cannot be resolved only on theoretical grounds. Theoretical arguments for and against the viability of a double dividend are clearly and concisely stated in Goulder [1995], Bohm [1997], Bovenberg [1999], and de Mooij [1999].

Previous empirical work on carbon dioxide emissions in Spain by Alcántara \& Roca [1995], Antón et al [1996], and Manresa \& Sancho [1997] was based on Leontief accounting methods. It therefore omitted a complete and disagregated view of the circular flow of income and did not fully incorporate economic behaviour and balance restrictions. Following the seminal Shoven-Whalley [1984] modelling tradition, we present in this paper a numerical general equilibrium model of the Spanish economy that incorporates a detailed fiscal structure. Our aim here is to contribute to the double dividend literature by way of setting up an applied microeconomic model that evaluates after-tax resource allocation and is thus able to compute $\mathrm{CO}_{2}$ emission levels and efficiency indicators. Since our micro model allows for the possibility of involuntary unemployment in equilibrium, we specifically address the question of whether an environmental tax accompanied by a budget neutral reduction in labour payroll taxes can be effective in promoting increased levels of employment. This strong version of the double dividend hypothesis is known in the literature as an employment double dividend. Several important contributions that have studied the viability of an employment double dividend (Carraro et al. [1996], Koskela \& Schob [1999], Holmlund \& Kolm [2000], among others) show that some degree of real wage flexibility and some feedback between unemployment and real wages are a key factor in attaining a double dividend. These contributions are essentially 
analytical and deal with small size economic models. Our paper, in contrast, attempts to provide an answer with a large size numerical model where general economic interdependence is fully taken into account. This is also the approach followed by Glowsrod et al. [1992] and Pireddu \& Dufournand [1996]

The numerical model is implemented using the rich data set contained in a Social Accounting Matrix of Spain. We find that under certain conditions on the structure of the economy it is indeed possible to obtain a double dividend. In this situation we show that a budget neutral tax reform can yield a better environment (i.e. a reduction of $\mathrm{CO}_{2}$ emissions), and at the same time improve the employment levels and the efficiency of the Spanish tax system. In fact, the reported situation could be termed as a triple dividend (Holmlund \& Kolm [2000]). The first type of result is to be expected since, in general, the introduction of an ecotax in the economy will lead to a less intensive use of the polluting energy sources and hence the environment will improve. It is unusual, however, to find in the literature that welfare, employment and emission levels improve once a fiscal policy of this type is implemented. The general argument against it is that in a general equilibrium setting a new energy tax will interact with the existing set of indirect taxes and will give rise to a less efficient (i.e., a more distortionary) tax system provoking that the double dividend policy will fail (see Bovenberg \& de Mooij [1994], de Mooij [1999 ], and Bovenberg \& Goulder [1996, 1997, and 2001])). Taxes on energy use to improve the environment are in fact shifted to primary factors (labour and capital) and thus the supply of these resources are distorted by the new taxes.

In our analysis we simulate a new tax system in which an ecotax (an ad-valorem tax on all energy goods) is introduced while payroll taxes are lowered across all production sectors under a budget neutral restriction. However, it is not always sufficient to lower the payroll taxes to compensate for the ecotax since the applicable tax base of both taxes are quite different in magnitude and scope and economic structure does matter, as we will see below. When we only consider, instead, a tax on a specific polluting energy use (i.e. a petrol tax ) the distortions that this tax introduces into the economy are greater than the previous policy and the double dividend does not hold. 
Another reason that helps to explain why the double dividend may be observed rests in the inefficiency of taxation over primary factors (labour and capital) in the Spanish fiscal system. We have a relatively high tax on labour use compared to taxes levied on capital that in our model (as in many others of the same type) is inelastically supplied. Hence the arguments of Bovenberg \& van ther Ploeg [1996] apply: we are in a situation where a shift from labour taxes towards pollution taxes amounts to a shift in tax incidence from labour towards the other immobile factor, thereby improving the efficiency of taxation. The way we model the labour market is very simple. The demand side comes from the usual cost minimisation of competitive firms. The supply side tries to capture an aggregate behaviour of the economy that links in a positive way real wages and aggregate labour supply, particularly the unemployment rate. Hence in equilibrium the model allows for an endogenous, positive unemployment rate.

Our model, due to data restrictions, contemplates a single representative consumer and thus the distributional aspects of various tax policies cannot be considered. Therefore we focus our analysis on efficiency issues only. The paper is organised as follows. Section 2 describes the assumptions and model characteristics of the general equilibrium implementation used in the simulations. We embed all tax simulations in two main scenarios. The first one is termed the rigid model and represents a version of the economy where the technology does not adjust in response to changing relative prices and unemployment is kept fixed; in the second one -the flexible version- we allow selection of techniques in primary factors in response to changing relative prices as well as adjustments in employment levels in responses to changing market conditions. By comparing the results in both scenarios we infer the role that flexibility adjustments may play in the occurrence of the double dividend. This is the aim of Section 3 where results are presented and commented. Finally, we end the paper in Section 4 with a summary of the main results. 


\section{The model}

\subsection{An overview}

The analysis we present follows the tradition of applied general equilibrium models of the Walrasian static variety. These type of models have been seen to yield fiscal policy simulation results that are satisfactory approximations of actual economic changes (see Polo \& Sancho [1993] and Kehoe et al [1995] for a discussion of model validation).

Applied general equilibrium models offer an integrated numerical representation of an economy in which typical agents such as producers, consumers, the government, and the foreign sector are duly incorporated. In essence, these models are disaggregate, microeconomic versions of the circular flow of income where all bilateral exchanges among agents are adequately captured, although always up to a level of operational institutional aggregation.

In our model consumption activities are those of a single representative consumer. The consumer demands goods and savings (future consumption) under an income constraint. Income is the result of selling endowments of labour and capital plus net transfers from the government. The production side distinguishes 22 industries of which 10 correspond to energy production activities. The energy industries keep the finer disaggregation present in the official input-output table while the rest of industries are aggregated according to production relatedness. Total output is a combination of domestic and imported outputs. Domestic output, in turn, is the result of combining primary factors (labour and capital) with intermediate goods following the available technological recipees.

The government plays a singular role in the model. It produces a public consumption good, supports public investments and provides the private sectors with income transfers. All these government expenditures are financed through taxes and, if necessary, with a complementary bond-financed deficit. Taxes are of two general types: a direct income tax and a suite of indirect taxes (production tax, value-added tax, labour tax, and tariffs). 
The foreign sector plays a residual but nonetheless important role in the model. We distinguish two foreign subsectors: the European Union (EU) and the Rest of the World (ROW). Imports are demanded by the domestic industries and they are used to yield, along with domestic output, the total supply of goods. Part of this total supply is in turn demanded by the foreign sectors as exports.

In the behavioural side, all agents are maximisers and price takers. The technology presents constant returns to scale. We consider two polar cases. In the first one - the rigid model - there is no factor substitution, nor adjustments in the initially given fix labour supply. In the second version of the model — the flexible model — firms can adjust their factor demands over a smooth isoquant and, moreover, there may be adjustments in the labour market that make the level of employment, or alternatively the unemployment rate, an endogenous variable.

In equilibrium all markets clear with the possible exception of the labour market. All labour is endowed to the representative consumer and we distinguish between used and non-used labour. In the rigid version the used labour supply is totally inelastic and we have a fix level of unemployment which is equal to the non-used part of the endowment. In the flexible version the consumer offers all labour elastically at the going real wage up to the point of use depletion. From here on, the labour supply becomes inelastic. If total labour demand at the going wage by the 22 industries is less than the labour endowment, that is, it intersects the labour supply at the elastic part, we happen to have involuntary unemployment. Notice that in this case unemployment is endogenously determined.

\subsection{A few more details}

Each of the 22 industries produces an homogeneous good using a nested constant returns to scale technology. Let us use, for $j=1, \ldots, 22$, the following notation:

$X_{j}$ : Total output

$X_{d j}:$ Domestic output 
$X_{e j}:$ EU imports

$X_{r j}:$ ROW imports

In the first level we posit a fixed coefficients production function:

$$
X_{j}=F_{\operatorname{Min}}\left(X_{d j}, X_{e j}, X_{r j}\right)
$$

In the second level, domestic output $X_{d j}$ is also obtained using a fixed coefficients technology that combines intermediate inputs $X_{i j}$ and value added $V A_{j}$ :

$$
X_{d j}=F_{M i n}\left(X_{1 j}, X_{2 j}, \ldots, X_{22 j}, V A_{j}\right)
$$

Here $V A_{j}$ stand for value-added -a composite primary factor generated by combining labour and capital services. In the third level of the nested technology, value-added can be generated through two different possibilities. Under the rigid assumption we have:

$$
V A_{j}=F_{\operatorname{Min}}\left(L_{j}, K_{j}\right)
$$

where $L_{j}$ and $K_{j}$ stand for labour and capital services. Under the flexible assumption we postulate a Cobb-Douglas substitution scheme:

$$
V A_{j}=F_{C D}\left(L_{j}, K_{j}\right)
$$

This completes the description of the technology. In a formal sense total output is generated following an Armington [1969] rule, although a very simple one indeed since we do not allow for substitution at the upper level of the nested technology. Under the constant returns to scale assumption, maximum profits will be zero and firm behaviour reduces to cost minimisation. 
On the consumption side, we have a standard utility maximisation problem. Utility derives from consumption and savings (future consumption) and consumption plans are the result of solving the Cobb-Douglas utility problem:

$$
\begin{aligned}
& \operatorname{Max} U_{C D}\left(C_{1}, C_{2}, \ldots, C_{22}, S\right) \\
& \text { subject to } \\
& \sum_{j=1}^{22} p_{j} \cdot C_{j}+p_{S} \cdot S=(1-t d) \cdot(w \cdot \bar{L} \cdot(1-u)+r \cdot \bar{K}+C P I \cdot G T)
\end{aligned}
$$

where $C_{j}$ is consumption of good $j, S$ represents savings, $t d$ is the direct income tax rate, $w$ and $r$ are factor prices, of labour and capital respectively, $\bar{L}$ and $\bar{K}$ are the labour and capital endowment, and $G T$ represents net transfers from the government. Prices for goods and savings are denoted by $p_{j}$ and $p_{S}$ whereas $C P I$ stand for a consumers price index. All prices are final prices, therefore inclusive of all indirect taxes. Notice that not all the endowment of labour is being necessarily used - the unemployment rate $u$ takes care of that. Consumption demand depends upon goods' prices and disposable income which in turn depends on factor prices and the unemployment rate. Hence $C=C(p, w, r, u)$.

The government collects tax income that is spent providing public consumption $P U B C$, public investment $P U B I$, and government transfers $G T$ to the private sector. We distinguish the following tax categories:

DIR: aggregate income tax

IND: production indirect tax

VAT: value-added tax

$S S C$ : payroll tax

TAR: tariffs

ECO: eco-tax.

Adding up income from all tax sources yields total tax collections TTC. On the other hand, for any given set of tax rates, tax collections will depend upon the applicable tax bases. For each 
tax category, the tax base depends on the interaction of prices and activity levels, thus their endogenous character. This can be described by a tax revenue function $T R$ :

$$
T R=T R(p, w, r, u, X)
$$

The government budget constraint takes the form:

$$
P U B D=T T C-C P U B-I P U B-I P C \cdot G T
$$

where $P U B D$ stands for the public deficit (or surplus). A slight rearrangement yields:

$$
P U B C+P U B I+I P C \cdot G T=T T C-P U B D
$$

Under this format we clearly see the financing role that the public deficit can play. Indeed, if the deficit is negative, the government is spending more that it collects and -PUBD can be interpreted as a loan (bonds, for instance) from the private sector to the government. There is a degree of freedom here. Either the level of spending is fixed - and the public deficit becomes endogenous - or the level of the deficit is fixed - and spending turns to be endogenous. Here we will be considering only the first option.

\section{$\underline{2.3 \text { Equilibrium }}$}

The equilibrium concept is essentially Walrasian with the added touch of a macro rule affecting the labour market. The relationship between the real wage and the unemployment rate takes on the following form (see Oswald [1982] for a justification):

$$
\frac{w}{I P C}=\left[\frac{1-u}{1-\bar{u}}\right]^{1 / \beta}
$$

where $u$ is the unemployment rate, $\bar{u}$ is the benchmark unemployment rate, and $\beta$ is an elasticity that measures the sensibility of the wage rate to the unemployment rate. It is worth remarking that $1 / \beta$ can be interpreted as a wage flexibility parameter. When $\beta=\infty$, the wage rate is totally 
rigid and unemployment is perfectly flexible. When $\beta=0$, unemployment is totally rigid (and equal to the benchmark level) and the wage rate is fully flexible. In the in-between cases, $0<\beta<\infty$, as $\beta$ increases the sensibility of the wage rate to the unemployment rate decreases. In the rigid version of the model we will take $\beta=0$, whereas in the flexible one we will assume $0<\beta<\infty$, with a value for $\beta$ that will be taken from the econometric literature (Andrés et. al [1990]).

An equilibrium is described by a vector of prices for goods and factors $\left(p^{*}, w^{*}, r^{*}\right)$, a vector of gross production outputs $X^{*}$, a level of gross capital formation $G K F^{*}$, a level of the public deficit $D P U B^{*}$, an unemployment rate $u^{*}$, and a level of tax collections $T T C^{*}$ such as:

i) Markets for goods clear:

$$
X^{*}=A \cdot X^{*}+C\left(p^{*}, w^{*}, r^{*}, u^{*}\right)+G K F^{*}+P U B C+\bar{E}-M\left(X^{*}\right)
$$

Notice that total output, $X^{*}$, needs to cover intermediate demand, $A \cdot X^{*}$, private consumption, $C\left(p^{*}, w^{*}, r^{*}, u^{*}\right)$, gross capital formation, $G K F^{*}$, government spending in public consumption $P U B C$, and the trade balance between a fixed demand for exports $\bar{E}$ and endogenously determined imports $M\left(X^{*}\right)$.

ii) Markets for factors "clear":

$$
\begin{aligned}
& \bar{K}=K^{D}\left(w^{*}, r^{*}, X^{*}\right) \\
& \bar{L} \cdot\left(1-u^{*}\right)=L^{D}\left(w^{*}, r^{*}, X^{*}\right)
\end{aligned}
$$

where $K^{D}$ and $L^{D}$ are conditional factors' demand.

iii) Total tax collections coincide with total tax payments from all sources by all agents:

$$
T T C^{*}=\operatorname{TR}\left(p^{*}, w^{*}, r^{*}, u^{*}, X^{*}\right)
$$


iv) Total investment equals savings by all agents:

$$
G K F^{*}=S\left(p^{*}, w^{*}, r^{*}, u^{*}\right)+D P U B^{*}+M\left(X^{*}\right)-\bar{E}
$$

\section{$2.4 \mathrm{CO}_{2}$ emissions}

$\mathrm{CO}_{2}$ emissions are a natural by-product of economic activities, in particular from the use of transformed fossil fuels in production and consumption. There is a direct "technological" link between the level of economic activity and the level of emissions. The emission technology is specified by fixed coefficients that show the emission volume (in metric tons) per unit of energy good being used. Since the equilibrium allocation depends, for a given set of preferences and technology, upon the tax structure, any government induced change in tax rates will affect resource allocation and therefore $\mathrm{CO}_{2}$ emissions.

The evaluation of $\mathrm{CO}_{2}$ emissions must take into account, on the production and final demand sides, only those emissions effectively taken place on the national territory. Therefore we should only count emissions generated in domestic production activities and in domestic final demand ruling out in this last case any exported emissions (through any energy exports). Total emissions can then be calculated as:

$$
C O_{2}=\sum_{k=2}^{11} \operatorname{emip}_{j} \cdot\left(\sum_{j=1}^{22} a_{k j} \cdot X_{d j}\right)+\sum_{k=2}^{11} \operatorname{emid}_{k} \cdot F D_{k}
$$

where emip $=\left(\right.$ emip $_{2}$, emip $_{3}, \ldots$, emip $\left._{11}\right)$ is the vector of production emission coefficients, and emid $=\left(\right.$ emid $_{2}$, emid $_{3}, \ldots$, emid $\left._{11}\right)$ is the vector of emission coefficients associated with the final domestic use of energy goods $F D_{k}$. Finally, $a_{k j}$ are technical coefficients showing the use of energy goods $k=2,3, \ldots, 11$, in the domestic production of a unit of good $j=1,2, \ldots, 22$.

\subsection{Model calibration}

Structural input-output and primary factors coefficients, as well as production and consumption share parameters are obtained through deterministic calibration from a 1990 
Social Accounting Matrix for Spain developed by the authors. In compiling the SAM data base the authors have made extensive used of official data such as the 1990 input-output table and the 1990 National Products and Income Accounts. Tax parameters are likewise determined from the same data base. All tax rates are ad-valorem effective rates, hence its levels are inclusive of any tax evasion that may be pervading the economy. Even if there were no tax evasion, calibrated rates would likely differ from nominal ones due to aggregation issues. The $\beta$ coefficient measuring the sensibility of the wage rate to unemployment is taken from the estimates of Andrés et al. [1990]. Emission coefficients are adapted versions of Eurostat estimates. Eurostat coefficients measure emissions per energy unit used in production or final use. The model, as is standard in the literature, is implemented using fictitious physical units that correspond to base year value units. It is therefore necessary to transform the Eurostat coefficients into model-ready coefficients. The adaptation is undertaken using unit energy indices available from a 1985 energy input-output table and energy price indices available from Spain's National Statistics Institute.

Calibration allows us to reproduce the base year data as a benchmark equilibrium against which we are able to compare counterfactual equilibria resulting from the possible adoption of new energy related tax policies.

\section{Ecotax and energy policies.}

The two versions of the model will serve as yardsticks to appraise the spread of likely effects ensuing the adoption of an ecotax policy. In addition to this, in each model version we will contemplate two alternative scenarios. The first one will consist in the adoption of a new set of tax rates on top of the existing tax rate system. In contrast, the second scenario will maintain the aggregate real level of government tax collections by way of a compensating decrease in Social Security contributions by employers which is the payroll tax considered in the analysis. The rationale for this recycling of tax revenues specifically targeting the labour market lies on the need to seek out ways that may improve labour occupation in Spain, a persistent negative feature that has characterised the Spanish economy in the last decade. 
The following tax policies are examined. First, the adoption of a 10 percent ecotax on the use of energy products. Second, a 15 percent increase in the effective tax rate levied on petrol and gasoline products. Third, both previous policies applied simultaneously. A summary of the simulation results appear in Tables I-V.

Table I shows the likely effects of adopting energy use taxes under the rigid version of the model and with no tax revenue recycling. In this polar case, the level of total $\mathrm{CO}_{2}$ emissions reduction could reach an up to 4 percent fall. Of these, about 19 percent could be ascribed to a change in the structure and level of final demand and about 1 percent to the restructuring of production activities. Both real income indicators - direct utility and money metric utility as measured by the equivalent variation index- show a very slight fall. Since the levels of employment and capital use are kept constant, the overall picture suggests that the slight contraction of aggregate economic activity is entirely due to an allocation shift conducing in turn to a substantial emissions reduction.

Table II is like table I but we consider a revenue neutral reduction in labour taxes. Overall emissions fall but slightly less than in the previous simulation. Interestingly though, production emissions fall a bit more and demand emissions a bit less than in the initial simulation. All real income indicators show, again, a very small contraction of economic activity accompanied by an allocation shift. The neutrality assumption leaves the overall picture almost the same except for the reduction in $\mathrm{CO}_{2}$ emissions which once more signals that an ecotax policy can be designed that is effective in noticeably lowering emissions with an added but small efficiency cost. In this case the efficiency cost, as measured by the equivalent variation, is clearly smaller than in the precedent simulation. Tax recycling works to temper the original utility loss. Neither Table shows the existence of a double dividend. A better environment comports here a definite private utility cost.

Tables III and IV display simulation results under the flexible version of the model. In these simulations unemployment is allowed to adjust endogenously while primary factor utilisation is governed by a smooth Cobb-Douglas isoquant. Table III exhibits the same unrestricted ecotax policies than table I above. Table IV, in turn, shows the policies under the same type of revenue neutral compensating scheme of Table II. Under the unrestricted policies, 
$\mathrm{CO}_{2}$ emissions would fall up to a 4.5 percent. All real income indices fall sharper than in Table I. This is likely due to the rise in unemployment that ensues the tax increase. The output effect that was suggested in Table I is here accompanied by a substitution effect that worsens the overall economic picture but offers an additional bonus in emissions reduction. When we study in Table IV the effects of the revenue neutral ecotax policies we observe that the reduction in employers' Social Security contributions yields an added positive impetus to the economy. The distinct reduction (of up to a 13 percent in tax rates) in the relative cost of using labour proves to be a sufficient stimulant to substitute capital for labour and reduce unemployment under the three policies.

Strikingly, the pure 10 percent ecotax policy yields an increase in utility and employment along with a 2.8 percent reduction in $\mathrm{CO}_{2}$ emissions. In the other two cases, employment opportunities go up but real income measured by direct utility and money metric utility fall. Empirically speaking there are two distinct double dividend situations. Column (a) shows in fact a triple dividend situation: unemployment falls, private utility raise, and emissions fall. In columns (b) and (c), however, utility falls while the other indicators maintain the beneficial improvement. These two policy scenarios correspond to the strongest sort of a double dividend, namely, the employment double dividend.

The results reported in these simulations should not be read as a "proof" of an actual double dividend but rather as a suggestion that a conveniently designed revenue neutral tax policy could indeed help move the economy in the direction of an eventual double beneficial improvement. A reduction in $\mathrm{CO}_{2}$ emissions and in increase in employment levels should not be seen as antagonistic policy objectives. The results also seem to suggest that "flexibility" in the labour market is a desirable property for an economy to have in order to improve its chances to achieve a double dividend. If so, policies that encourage and stimulate changes towards flexibility should be given adequate attention and be globally evaluated by authorities. The working hypothesis that more flexibility, in terms of lesser labour market rigidities or even better technological adaptability, seem to imply better prospects for a double dividend should therefore be carefully checked out. An attempt is presented in Table V where we show the simulation results of a labour market scenario with a sensibility elasticity of $\beta=\infty$. In this 
polar case, we have a labour market situation in which the real wage is totally rigid and unemployment is perfectly flexible.

The enhanced labour market flexibility gives rise, as expected, to a sharper fall in the unemployment rate compared to the decrease reported in Table IV. As a result of the greater available labour income, we observe utility gains in all three tax scenarios. The expanding economy, however, gives rise to systematic increases in $\mathrm{CO}_{2}$ production related emissions. There is an overall fall in carbon dioxide but this is due to the containment in emissions from consumption. Consumers shift their consumption demand to less polluting goods and services, whereas production activities seem to expand in a more homogeneous way in response to the larger across the board reduction in payroll taxes. In the situation described in Table V, we again observe the presence of a triple benefit (better environment, more employment, and larger real income than in the base case) but it is relevant to mention the changing sign in the level of emissions derived from production activities More flexibility in the labour market does not necessarily yield better or dominant double dividend situations. A larger increase in output may offset the environmental gains, as measured by $\mathrm{CO}_{2}$ emissions, associated with a more efficient tax system.

\section{Concluding remarks}

Using an applied general equilibrium model of the Spanish economy implemented with a Social Accounting Matrix we have explored the virtuality of a double dividend following the adoption of an ecotax on energy goods. The model incorporates a few key aspects on the labour market. First, we contemplate the possibility of involuntary unemployment in equilibrium. Second, the real wage rate and the unemployment rate are linked through an elasticity that measures labour market rigidities. Finally, the wage rate and the unemployment rate are determined endogenously.

There are two main conclusions in this report. The first one is that an employment double dividend (lower $\mathrm{CO}_{2}$ emissions and lower unemployment) is an empirical possibility under a rather standard set of model characteristics. The second one attests to the fact that, up to a point, a more flexible labour market responds better to the stimuli of tax policies directed 
to contain emissions and improve labour utilisation. To achieve this double goal, revenue neutral tax policies are necessary but not always sufficient.

The main advantage of using a general equilibrium model is its ability to capture the fine details of resource allocation and economic interdependence in response to changing tax parameters. A limitation of the analysis is the data base age. An operational data base is compiled using officially published input-output tables, expenditure surveys, and national product and income accounts. Unfortunately, these data sources are not updated with the required, for the modeller anyway, speed and a few compromises linking and unifying them in a micro consistent way have to be adopted. This is the reason that simulations results showing a double dividend should just be taken as indications of what may be possible and not as any definite proof.

On general economic grounds, however, a strong point can be made to support energy tax policies as a singular tool of choice for achieving a better environmental quality and a lower unemployment at zero revenue cost. 


\section{$\underline{\text { References }}$}

Alcantára, V. \& J. Roca [1995], "Energy and $\mathrm{CO}_{2}$ Emissions in Spain: Methodology of Analysis and some results for 1980-90", Energy Economics, 17(3), 221-230.

Andrés, J. JJ. Dolado, C. Molinas, M. Sebastián \& A. Zabalza [1990], "The Influence of Demand and Capital Constraints on Spanish Unemployment", in Europe's Unemployment Problem, J. Drèze \& C. Bean (editors), MIT Press, Cambridge, USA.

Antón, V., A. de Bustos, J.A. Herce \& S. Sosvilla (1996), "Environmental Consequences of the Community Support Framework 1994-99: Energy consumption and associated $\mathrm{CO}_{2}$ emissions in Spain. A HERMIN-model based simulation', FEDEA, Documento de Trabajo 96-06.

Armington, P. [1969], "A Theory of Production Distinguished by Place of Production", IMF Staff Papers, number 16(1), 159-178.

Bohm, P. [1997], "Environmental Taxation and the Double Dividend: Fact or Fallacy", In Ecotaxation, T. O'Riordan (editor), EarthScan, London.

Bovenberg, L. [1999], "Green tax reforms and the double dividend: an updated reader's guide", International Tax and Public Finance, 6, 421-443.

Bovenberg, L. \& R. A. de Mooij [1994], "Environmental levies and distortionary taxation", American Economic Review, 94, 1085-9.

Bovenberg, L. \& Van der Ploeg (1994), "Environmental Policy, Public Finance and the Labour Market in a Second-Best World", Journal of Public Economics, 55, 349-390.

Bovenberg, L. \& Van der Ploeg [1996], "Optimal Taxation, Public Goods and Environmental Policy with Involuntary Unemployment", Journal of Public Economics, 62, 59-83.

Bovenberg, L. \& Van der Ploeg [1998], "Tax reform, structural unemployment and the environment. Scandinavian Journal Economics, 100 (3), 593-610

Bovenberg, L. \& L. H. Goulder [1996]. "Optimal environmental taxation in the presence of other taxes: General Equilibrium Analyses". American Economic Review, 86, nº4, 985-1000.

Bovenberg, L. \& L. H. Goulder [1997]. "Cost of environmentally motivated taxes in the presence of other taxes: general equilibrium analyses", National Tax Journal, 50(1), 59-87. 
Bovenberg, L. \& L. H. Goulder [2001] . "Environmental taxation and Regulation" NBER Working Paper 8458. In Handbook of Public Economics, Second Edition, A. Auerbach \& M. Feldstein (editors), North Holland, New York, USA

Carraro, C., M. Galeotti \& M. Gallo [1996] "Environmental taxation and unemployment: some evidence on the double dividend hypothesis in Europe". Journal of Public Economics, 62, 141-181.

Goulder, L.H. [1995], "Environmental taxation and the "double dividend": a reader's guide". International Tax and Public Finance, 2, 155-182.

Glowsrod, S., H.Vennemo \& T. Johnsen (1992). "Stabilization of Emissions of $\mathrm{CO}_{2}$ : A Computable General Equilibrium assessment", Scadinaviam Journal of Economics, 94/1, 53-69.

Holmlund, B. \& A. S. Kolm [2000], "Environmental Tax Reform in a Small Open Economy with Structural Unemployment", International Tax and Public Finance, 7(3), 315-333.

Kehoe, T., C. Polo \& F. Sancho [1995], "An Evaluation of the Performance of an Applied General Equilibrium Model of the Spanish Economy", Economic Theory, 6, 115-141.

Kosquela, E. \& R. Schöb [1999], "Alleviating Unemployment: the Case for Green Tax Reform", European Economic Review, 43, 1723-1746.

Manresa, A. \& F. Sancho [1997], "El análisis medio-ambiental y tabla input-output : Cálculos energéticos y emisiones de $\mathrm{CO}_{2} "$. Regidoria-Presidència de la Comisió de Medi Ambient i Serveis Urbans. Ajuntament de Barcelona.

Mooij, de R.A. [1999], "The double dividend of an environmental tax reform". In Handbook of Environmental and Resource Economics, Van der Bergh (editor), Edward Elgar, London.

Pireddu, G. y C.M. Dufournand [1996], "Eco-taxes in an Italian CGE model: Double dividend effects and the distribution of tax burdens." In Economic Modelling under the Applied General Equilibrium Approach, A. Fossati (editor), Avebury Press, Great Britain.

Polo, C. \& F. Sancho [1993], "Insights or Forecasts?. An Evaluation of a Computable general Equilibrium Model of Spain", Journal of Forecasting, 12, 437-448.

Shoven, J. \& J. Whalley [1984], "Applied General Equilibrium Analysis of Taxation and Trade", Journal of Economic Literature, 22(3), 1007-105. 


\section{$\underline{\text { Table I : Ecotax effects }}$}

i) rigid model

ii) no labour tax compensation

\begin{tabular}{|l|c|c|c|c|}
\hline Indicators & base situation & (a) $\mathbf{1 0} \%$ ecotax & (b) $\mathbf{1 5 \%} \Delta$ petrol tax & (a) $+(\mathbf{b})$ \\
\hline Unemployment in $\%$ & 16,250 & 16,250 & 16,250 & 16,250 \\
\hline$\% \Delta$ utility & - & $-0,013$ & $-0,002$ & $-0,016$ \\
\hline Equivalent variation $^{\mathrm{a}}$ & - & $-561,940$ & $-100,815$ & $-671,745$ \\
\hline$\% \Delta$ production emissions & - & $-1,028$ & $-0,055$ & $-1,083$ \\
\hline$\% \Delta$ demand emissions & - & $-15,195$ & $-4,329$ & $-18,921$ \\
\hline$\% \Delta$ total emissions & - & $-3,382$ & $-0,765$ & $-4,046$ \\
\hline
\end{tabular}

a. in millions of 1990 pesetas.

\section{Table II : Ecotax effects}

i) rigid model

ii) with labour tax compensation

\begin{tabular}{|c|c|c|c|c|}
\hline Indicators & base situation & (a) $10 \%$ ecotax & (b) $15 \% \Delta$ petrol tax & (a) + (b) \\
\hline$\% \Delta$ in labour tax & - & $-11,416$ & $-1,728$ & $-13,044$ \\
\hline Unemployment in \% & 16,250 & 16,250 & 16,250 & 16,250 \\
\hline$\% \Delta$ utility & - & $-0,003$ & $-0,001$ & $-0,004$ \\
\hline Equivalent variation $^{\mathrm{a}}$ & - & $-111,768$ & $-36,868$ & $-156,512$ \\
\hline$\% \Delta$ production emissions & - & $-1,091$ & $-0,064$ & $-1,155$ \\
\hline$\% \Delta$ demand emissions & - & $-13,878$ & $-4,125$ & $-17,469$ \\
\hline$\% \Delta$ total emissions & - & $-3,214$ & $-0,739$ & $-3,865$ \\
\hline
\end{tabular}

a: in millions of 1990 pesetas. 


\section{$\underline{\text { Table III : Ecotax effects }}$}

i) flexible model $(\beta=1.25)$

ii) no labour tax compensation

\begin{tabular}{|l|c|c|c|c|}
\hline Indicators & base situation & (a) $\mathbf{1 0 \%}$ ecotax & (b) $\mathbf{1 5 \%}$ petrol tax & (a) + (b) \\
\hline Unemployment in \% & 16,250 & 17,070 & 16,400 & 17,260 \\
\hline$\% \Delta$ utility & - & $-0,162$ & $-0,298$ & $-1,954$ \\
\hline Equivalent variation $^{\text {a }}$ & - & $-676,540$ & $-124,393$ & $-815,239$ \\
\hline$\% \Delta$ production emissions & - & $-1,573$ & $-0,158$ & $-1,749$ \\
\hline$\% \Delta$ demand emissions & - & $-15,064$ & $-4,337$ & $-18,806$ \\
\hline$\% \Delta$ total emissions. & - & $-3,81$ & $-0,852$ & $-4,582$ \\
\hline
\end{tabular}

${ }^{a}$ : in millions of 1990 pesetas

\section{Table IV : Ecotax effects}

i) flexible model $(\beta=1.25)$

ii) with labour tax compensation

\begin{tabular}{|l|c|c|c|c|}
\hline Indicators & base situation & (a) $\mathbf{1 0 \%}$ ecotax & (b) $\mathbf{1 5 \%} \Delta$ petrol tax & (a) + (b) \\
\hline$\% \Delta$ in labour tax & - & $-11,420$ & $-1,730$ & $-13,040$ \\
\hline Unemployment in \% & 16,250 & 15,620 & 16,190 & 15,600 \\
\hline$\% \Delta$ utility & - & 0,050 & $-0,047$ & $-0,043$ \\
\hline Equivalent variation $^{\text {a }}$ & - & 20,928 & $-19,707$ & $-18,319$ \\
\hline$\% \Delta$ production emissions & - & $-0,688$ & $-0,023$ & $-0,737$ \\
\hline$\% \Delta$ demand emissions & - & $-13,520$ & $-4,081$ & $-17,110$ \\
\hline$\% \Delta$ total emissions & - & $-2,820$ & $-0,697$ & $-3,457$ \\
\hline
\end{tabular}

${ }^{\mathrm{a}}$ : in millions of 1990 pesetas 


\section{Table V: Ecotax effects}

i) flexible model $(\beta=\infty)$

ii) with labour tax compensation

\begin{tabular}{|c|c|c|c|c|}
\hline Indicators & base situation & (a) $10 \%$ ecotax & (b) $15 \% \Delta$ petrol tax & (a) + (b) \\
\hline$\% \Delta$ in labour tax & - & $-15,020$ & $-2,110$ & $-16,780$ \\
\hline Unemployment in \% & 16,250 & 13,920 & 16,020 & 13,820 \\
\hline$\% \Delta$ utility & - & 1,139 & 0,063 & 1,087 \\
\hline Equivalent variation $^{\mathrm{a}}$ & - & 474,929 & 26,391 & 453,569 \\
\hline$\% \Delta$ production emissions & - & 0,375 & 0,085 & 0,369 \\
\hline$\% \Delta$ demand emissions & - & $-12,474$ & $-3,964$ & $-16,065$ \\
\hline$\% \Delta$ total emissions & - & $-1,759$ & $-0,587$ & $-2,361$ \\
\hline
\end{tabular}

a: in millions of 1990 pesetas 